\section{Quality documentation and records management: a survey of Turkish universities}

Quality records management

Özgür Külcü

Department of Information Management, Hacettepe University, Ankara, Turkey
459

Received 10 May 2008

Revised 15 August 2008 Accepted 20 October 2008

\begin{abstract}
Purpose - The purpose of this paper is to assess the records system of a Turkish public university, using the example of Hacettepe University in order to develop records management programs in Turkish universities.

Design/methodology/approach - A survey method is used in this research; data are gathered through literature reviews, legal analysis, questionnaires, and interviews. Analyzing the information gathered concerning the differences and commonalities of the systems will allow researchers to develop solutions for records management.

Findings - The paper finds that institutional processes in Turkish public universities relating to records are not able to meet legal and administrative requirements, and this inadequacy resulted from erroneous applications, insufficient legal regulations, lack of quality-based administrative structure, ineffective records management systems, and unqualified staff.

Originality/value - This paper uses analysis techniques specific to the records management and quality management fields in order to provide information about the administrative systems needed for quality-based systems documentation.
\end{abstract}

Keywords Records management, Quality management, System documentation, Universities, Turkey

Paper type Research paper

\section{Introduction}

One of the fundamental aims of organizations nowadays is to achieve "quality." Designing a road map to attain quality requires considering the concept as a whole: developing policies, procedures, and practices which include every institutional component; transforming these into written documents; and implementing, evaluating, and controlling the system in accordance with these documents. While the documents prepared in light of outside standards and institutional needs illuminate the institution's future, records illuminate the institution's past. To achieve institutional quality, both preparing documentation about administrative systems and also implementing a records management program are extremely important. Analyzing the administrative and legal systems of institutions is the first step toward developing the document and records programs fundamental for designing quality-based systems (Brumm, 1996; Schlickman, 2003). Therefore, this paper aims to prepare quality system documentation requirements for the records system of Hacettepe University, a well-known Turkish university and a leader among Turkish public universities with regard to scientific publications in social science citation index, science citation index , and arts and humanities citation index (Academic Ranking of World Universities, 2006).

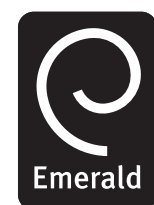

Aslib Proceedings: New Information Perspectives

Vol. 61 No. 5, 2009 pp. $459-473$

(C) Emerald Group Publishing Limited 0001-253X

DOI 10.1108/00012530910989616 
AP

61,5

460

\section{Methodology and analysis}

This paper attempts to describe the current condition, procedures, and problems of Hacettepe University (HU) records system according to the survey results. As part of the survey, questionnaires and interviews were carried out in all divisions having file units in the HU records system. The research supported the hypothesis that the institutional processes associated with records could not be realized through legal and administrative necessities in Turkish public universities (example Hacettepe University) because of erroneous applications, insufficiency of legal regulations, lack of quality-based administrative structure, ineffective records management system, unqualified staff (Külcü 2005, p. 6). As a result of this research, documentation of the records retention program for quality management has been completed for the Hacettepe University Beytepe Campus.

To confirm the research hypothesis, legal and administrative analyzes were realized. In terms of legal analysis, legal regulations affecting or determining records procedures in the Turkish juridical system were examined. Three aspects of legal regulations were evaluated:

(1) Legal conditions affecting or determining records procedures throughout the Turkish juridical system were analyzed.

(2) Regulations determining institutional policy and procedures were analyzed for their effects on records practices.

(3) The legal condition of the Turkish university system as this affects or determines records practices was analyzed.

In this context, 12 laws, six regulations, three circulars and one charter, all related to government institutions and affecting records procedures in Turkish governmental organizations, were examined. In addition 52 laws, 12 statutory decrees, 77 Council of Ministers declarations, 63 regulations, four circulars and seven reports and directories affecting or determining records issues in the Turkish higher education system and at Hacettepe University were examined. Space prevents the presentation of the findings of the legal analysis; however, results of the administrative analysis are presented in the following sections.

Data for analysis were gathered by means of participant observation, interviews, and questionnaires in academic and administrative units having individual file units in the HU records system. As part of the administrative analysis, the administrative structure and the organizational flow of the institution was investigated, and the distribution of staff who were responsible for or actually executed records work and records processes was described - involving an examination of everything from small units to the presidency. Questionnaires were distributed in a total of six faculties, 48 departments, five department divisions, four institutes, three schools, five research centres, and the 17 administrative units of the presidency. The questionnaires of 186 participants executing or responsible for records issues were analyzed. The questionnaire was designed to gather information about the present condition of administrative structures and organizational communication systems and about parts of the organization in need of overhaul using quality approaches (Blow, 1995; Brumm, 1996; Rao et al., 1996). Also, units creating or receiving records as part of their operations were examined from a records management perspective, and records and archival procedures and practices (Brumm, 1997; Hare and McLeod, 1997; 
Langemo, 1995; Montaña, 1997; Penn et al., 1994; Skupsky, 1994) were analyzed in terms of quality system documentation (Berry, 1998; Brumm, 1996; Schlickman, 2003) according to the information received from the questionnaire.

The questionnaire consisted of closed- and open-ended questions. With some questions, participants were able to select more than one option and to prioritize them with one (most important) to five (least important). Participants were sorted into three groups for more reliable evaluation of descriptive questions. The HU hierarchy and formal communication chain were the basis for the groups. Table I shows the groups and the number of staff in each.

Some questionnaire responses were presented on a five-point Likert scale: $1=\mathrm{SD}$, Strongly disagree; $2=\mathrm{D}$, Disagree; $3=\mathrm{N}$, Neutral; $4=\mathrm{A}$, Agree; $5=\mathrm{SA}$, Strongly agree. Likert-scale responses were analyzed by calculating mean rates (X: the mean of a statistical distribution with a discrete random variable, or the mathematical average of all the terms) and standard deviation for calculating deviations of responses ( $s$ : the standard deviation, or a measure of the spread of the values in a data set; for example, $s$ larger than 1.00 would mean uncertain or scattered responses). This paper will include only part of the results of the administrative analysis.

\section{Hacettepe University}

Hacettepe University was founded on July 8, 1967. Currently, the university has nine faculties, 15 vocational schools, 20 institutes, and 24 research centres. $\mathrm{HU}$ is a state university, supported mainly by state funds allocated by the Turkish Parliament. Over 150 different undergraduate degree programs are offered, along with more than 173 different degree programs for postgraduate studies. HU Beytepe Campus has six faculties, three institutes, two schools, five research centres, seven directorates, and six schools. The Faculty of Letters has 15 departments, Faculty of Education six, Faculty of Science four, Faculty of Fine Arts five, Faculty of Engineering nine, and Faculty of Economics five. HU has 3,748 full-time academic staff and 4,643 administrative staff (Hacettepe Üniversitesi Strateji Geliştirme Daire Başkanlığı 2006). HU has about 30,000 students enrolled for undergraduate studies and 3,011 for postgraduate. The total HU budget for 2006 was US\$235,059,000 (total revenues without staff expenditures) (Hacettepe Üniversitesi, 2006). HU was ranked 339th in Shanghai Jiao Tong University's “Top 500 Universities” list (2005).

Results of the administrative analysis of the HU records system: descriptive statistics As part of the administrative analysis, first the number of staff executing or responsible for records processes was investigated. Based on job titles, 326 of a total of 836 administrative staff could be identified as responsible for records issues. Participant observation and interviews indicated, however, that a total of 1,216 staff

Total number Percentage

Group I. Departments and divisions at HU

Group II. Deans' offices, institutes, schools and research centers at HU

Group III. Presidency and service and support units at HU

Total
Quality records management

461 
AP

61,5

462

carried out records processes at HU. Next, a survey was undertaken, with a total of 186 staff correctly filling out the questionnaire. Table II provides descriptive statistics about the educational level and total service periods for staff who executed or were responsible for records issues.

Among the 183 staff members who responded to the question about educational level, a total of 59 (32.2 percent) had graduated from junior high school and 64 (35.0 percent) from high school, while 55 (30.1 percent) have bachelor's degrees and five (2.7 percent) have master's degrees. However, the data also indicated that the educational level of the staff had risen over time. For instance, a bachelor's degree was the most common educational level for workers with less than five years' experience (37.3 percent), while high school was most common among workers with six to ten years' experience (41.5 percent) and junior high for those with 11 to 20 years (35.4 percent).

In contrast, the educational levels of records management professionals are quite different from the general educational profile summarized in Table II. For example, a total of 5.1 percent of staff who executed records work at HU reported graduation from a professional school, while 9.2 percent of staff reported taking training or other professional courses. Unfortunately, 85.7 percent of staff who executed or were responsible for records procedures indicated that they carried out these tasks without help from any professional unit of the university. Table III lists job titles of staff who executed or were responsible for records practices.

Based on job titles, most staff who fulfilled records procedures consisted of administrative officials (31.2 percent), computer operators (27.4 percent), administrative chiefs (14.5 percent), and typists (11.8 percent). Academic titles were associated with less than 10 percent of staff. Because the job descriptions of administrative officials, computer operators, and typists included records work these results are to be expected. Table IV indicates the distribution of staff who executed records work at $\mathrm{HU}$.

Table IV includes the responses of 179 participants. According to the results, 46.5 percent of staff who executed records procedures worked in faculties, 40 percent in directorates, and 11.4 percent in institutes or schools. In the faculties, the largest

Table II.

Educational level and total service periods of HU staff responsible for records

\begin{tabular}{lccccc}
\hline & Junior school & High school & Bachelor's degree & Master's degree & Total \\
\hline Less than five years & 13 & 16 & 19 & 3 & 51 \\
Service life (\%) & 25.5 & 31.4 & 37.3 & 5.9 & 100 \\
Educational level (\%) & 22.0 & 25.0 & 34.5 & 60.0 & 27.9 \\
Between six-ten years & 13 & 17 & 11 & 0 & 41 \\
Service life (\%) & 31.7 & 41.5 & 26.8 & 0 & 100 \\
Educational level (\%) & 22.0 & 26.6 & 20.0 & 0 & 22.4 \\
Between 11-20 years & 23 & 22 & 19 & 1 & 65 \\
Service life (\%) & 35.4 & 33.8 & 29.2 & 1.5 & 100 \\
Educational level (\%) & 39.0 & 34.4 & 34.5 & 20.0 & 35.5 \\
Longer than 21 years & 10 & 9 & 6 & 1 & 26 \\
Service life (\%) & 38.5 & 34.6 & 23.1 & 3.8 & 100 \\
Educational level (\%) & 16.9 & 14.1 & 10.9 & 20.0 & 14.2 \\
Total & 59 & 64 & 55 & 2.7 & 183 \\
\% & 32.2 & 35.0 & 30.1 & & 100 \\
\hline
\end{tabular}




\begin{tabular}{lcccc}
\hline Administrative staff & $N$ & Percentage & $\begin{array}{r}\text { Quality records } \\
\text { management }\end{array}$ \\
\cline { 1 - 3 } Secretary for a faculty, school, or institute & 3 & 1.8 & & \\
Head of unit & 1 & 0.6 & \\
Chief & 27 & 34.1 & $\mathbf{4 6 3}$ \\
Official & 58 & 30.4 & \\
Computer operator & 51 & 13.1 & \\
Typist & 22 & 1.2 & \\
Engineer & 2 & 1.8 & Table III. \\
Technician & 3 & 0.6 & \\
Academic & 18 & 100 & Definitions of tasks of the \\
Vice president of the department & 1 & 11.1 & staff conducting or \\
Total of administrative staff & 186 & 88.9 & responsible for records \\
Academic staff & 2 & 100 & procedures \\
Lecturer PhD & 16 & & \\
Research assistant & 18 & &
\end{tabular}

\begin{tabular}{lcc}
\hline & $N$ & Percentage \\
\hline Records staff distribution of the faculties & & \\
Faculty of Letters & 21 & 5.0 \\
Faculty of Science & 16 & 19.0 \\
Faculty of Education & 10 & 21.4 \\
Faculty of Engineering & 18 & 10.7 \\
Faculty of Economics & 9 & 11.9 \\
Faculty of Fine Arts & 10 & 100 \\
Total staff of the faculties & 84 & 28.6 \\
Institutes and schools & 6 & 33.3 \\
Institute of Science & 7 & 4.8 \\
Institute of Social Science & 1 & 14.3 \\
Atatürk Institute for Modern Turkish History & 3 & 9.5 \\
School of Foreign Languages & 2 & 9.5 \\
School of Sport Science and Technology & 2 & 100 \\
Coordinator of Schools & 21 & 18.9 \\
Total staff of the institutes and school & & 28.4 \\
Directorates & 14 & 18.9 \\
Directorate of Administrative and Financial Affairs & 21 & 10.8 \\
Directorate of Personnel Affairs & 14 & 13.5 \\
Directorate of Student Affairs & 8 & 8.1 \\
Directorate of Computer Affairs & 10 & 1.4 \\
Directorate of Health, Culture, and Sports Affairs & 6 & 100 \\
Directorate of Construction and Technical Works & 1 & Records staff distribution \\
Directorate of Library and Documentation Affairs & 74 & Table IV. \\
Total staff of the directories & & \\
P & & \\
\end{tabular}

number is employed in the Faculty of Letters, followed by the Faculty of Engineering. The Faculty of Fine Arts has the smallest number of staff. This result is in proportion to the size of the faculties. Among the directorates, Personnel Affairs has the most staff (28.4 percent), followed by the Directorate of Administrative and Financial Affairs and 
AP

61,5

464 the Directorate of Student Affairs (each 18.9 percent). Table V identifies the managerial positions of staff who executed or were responsible for record issues.

Data in Table $\mathrm{V}$ show that a majority of the staff who are responsible for records procedure in the institution are official workers (89.5 percent). The rate of administrators who are responsible for records procedure is 10.5 percent. This table indicates that approximately there is one administrator for each nine workers within the institution on the records processes.

Total number of records created or received in academic and administrative units at $H U$ Table VI shows the total number of records created or received in academic and administrative units at HU in a single year. All departments must make an inventory of incoming and outgoing records for each year.

Table VI charts the total number of incoming or outgoing records for $\mathrm{HU}$ administrative and academic units. The total number of outgoing records for 2005 was 127,928; the total incoming was 125,091. The flow of the records was greatest in the Faculty of Letters, the Faculty of Science, the Faculty of Engineering, and the Presidency, with the other units as well as institutes, schools, and research centres following. Among departments, the largest number of outgoing records was created in the Department of Chemistry, and the largest number of incoming records was received in the Department of Geological Engineering. Among the faculties, the Faculty of Letters had the heaviest record traffic. Among the institutes, the Institute of Social Science had the most records. Among the research centres, the largest numbers of outgoing records exist in Environment Research and the Application Center. Among $\mathrm{HU}$ administrative units, records flows were high in the Directorate of Student Affairs, the Directorate of Personnel Affairs, and the Directorate of Administrative and Financial Affairs. Table VII summarizes the records flow of the administrative and academic units.

The total number of records created or sent to other units by HU departments was approximately 41,129 in 2005 . Of the total number, 8,668 records were sent to institutions outside HU. Thus, approximately 93 percent of records created in $\mathrm{HU}$ units were being used only at HU. Legally, it is necessary to make at least one duplicate copy of a record at each step of the formal communication process in the HU hierarchy. For instance, a record created to be sent to an outside organization must stop at three different points and each point makes one copy according to the Turkish juridical system. As a result, more than half of the total 125,000 records created on campus consist of duplicates. This highlights a very serious problem for the HU records system.

Table V.

Managerial positions of records staff

\begin{tabular}{lcc}
\hline & $n$ & Percentage \\
\hline Manager & 5 & 2.9 \\
Vice manager & 4 & 2.3 \\
Head of department & 1 & 6.0 \\
Head of unit & 8 & 4.7 \\
Office worker & 154 & 89.5 \\
Total & 172 & 100 \\
\hline
\end{tabular}




\begin{tabular}{|c|c|c|c|}
\hline Faculty of Letters & Outgoing & Incoming & management \\
\hline Dean’s Office & 15,575 & 12,250 & \\
\hline Department of German Language and Literature & 377 & 0 & \\
\hline Department of American Language & 352 & 565 & \\
\hline Department of Anthropology & 348 & 516 & \\
\hline Department of Archeology & 358 & 80 & 465 \\
\hline Department of Philosophy & 432 & 1,025 & \\
\hline Department of French Language and Literature & 273 & 0 & \\
\hline Department of English Language & 403 & 945 & \\
\hline Department of Information Management & 384 & 292 & \\
\hline Department of Translation & 318 & 636 & \\
\hline Department of Psychology & 612 & 732 & \\
\hline Department of Art History & 559 & 864 & \\
\hline Department of Sociology & 653 & 775 & \\
\hline Department of History & 538 & 600 & \\
\hline Department of Turkish Language and Literature & 616 & 481 & \\
\hline Department of English Literature & 385 & 570 & \\
\hline Total of the departments & 6,608 & 8,081 & \\
\hline Sum of total (Dean office and departments) & 22,183 & 20,331 & \\
\hline Faculty of Education & & & \\
\hline Dean's Office & 3,935 & 3,754 & \\
\hline Department of Educational Science & 919 & 841 & \\
\hline Department of High School Education & 550 & 736 & \\
\hline Department of Primary School Teaching & 1,201 & 3,187 & \\
\hline Department of Foreign Languages Teaching & 650 & 1,050 & \\
\hline Department of Computer Education and & & & \\
\hline Instructional Technologies & 270 & 388 & \\
\hline Department of Primary Education & 1,300 & 2,500 & \\
\hline Total of the departments & 4,890 & 8,702 & \\
\hline Sum of the total (Dean office and departments) & 8,825 & 12,456 & \\
\hline Faculty of Science & & & \\
\hline Dean's Office & 5,340 & 5,318 & \\
\hline Department of Biology & 2,335 & 2,000 & \\
\hline Biotechnology & 0 & 0 & \\
\hline Botany & 1,601 & 1,381 & \\
\hline General Biology & 528 & 3,241 & \\
\hline Hydrobiology/Zoology & 720 & 840 & \\
\hline Department of Statistics & 952 & 720 & \\
\hline Department of Chemistry & 4,567 & 3,250 & \\
\hline Student Secretariat and Divisions & 2,100 & 1,900 & \\
\hline Department of Mathematics & 1,330 & 1,301 & \\
\hline Total of the departments & 14,133 & 14,633 & \\
\hline Sum of the total (Dean Office and departments) & 19,473 & 19,951 & \\
\hline Faculty of Fine Arts & & & \\
\hline Dean's Office & 2,500 & 2,722 & \\
\hline Department of Graphic Art & 759 & 0 & \\
\hline Department of Sculpture & 357 & 613 & Table VI. \\
\hline Department of Interior Design & 224 & 1,200 & Number of records \\
\hline Department of Painting & 630 & 486 & created and received at \\
\hline Department of Ceramics & 596 & 500 & academic and \\
\hline Selective Curriculum Coordinator & 0 & 0 & administrative units, \\
\hline & & (continued) & HU Beytepe Campus \\
\hline
\end{tabular}




\section{AP \\ 61,5}

466
Faculty of Letters

Total of the departments

Sum of the total (Dean's office and departments)

Faculty of Engineering

Dean's Office

Department of Computer Engineering

Department of Environmental Engineering

Department of Electrical and Electronics

Engineering

Department of Physics Engineering

Department of Food Engineering

Department of Geological Engineering

Department of Chemical Engineering

Department of Mining Engineering

Department of Nuclear Engineering

Total of the departments

Sum of the total (Dean's office and departments)

Faculty of Economics

Dean's Office

Department of Economy

Department of Management

Department of Public Administration

Department of Finance

Department of International Relations

Total of the departments

Sum of the total (Dean's office and departments)

Institutes and Schools

Institute of Social Science

Institute of Pure and Applied Science

Institute of Turcology Research

Atatürk Institute for Modern Turkish History

Head of Vocational Schools

School of Foreign Languages

School of Sport Science and Technology

Total

Research and Application Centers

Environment Research and Applications Center

Center for Karst Water Resources

Research Center for Human Rights

Hydropolitics and Strategic Research Center

Actuarial Sciences Applications and Research Center

Total

Administrative Units

President and General Secretary Unit

External Relations

General Records Office

Directorate of Administrative and Financial Affairs

Internal

External

Computer Center

Directorate of Student Affairs
Outgoing

Incoming

2,566

5,066

2,799

5,521

8,417

700

3,934

200

800

400

1,058

1,235

945

3,416

1,042

767

350

9,713

18,130

5,000

833

800

730

522

334

3,219

8,219

6,296

5,000

202

900

2,580

1,146

16,124

1,065

1,401

1,148

0

1,050

6,000

3,766

1,500

14,664

18,598

3,000

983

985

1,302

1,015

443

4,728

7,728

4,286

5,000

250

0

0

2,645

1,059

13,240

0

541

10,374

1,429

850

1,770

5,213 


\begin{tabular}{|c|c|c|c|c|c|}
\hline \multicolumn{2}{|l|}{ Faculty of Letters } & \multicolumn{2}{|c|}{ Outgoing } & Incoming & management \\
\hline \multicolumn{2}{|l|}{ Library and Documentation Center } & \multicolumn{2}{|c|}{336} & 27 & \\
\hline \multicolumn{2}{|l|}{ Directorate of Construction and Technical Works } & \multicolumn{2}{|c|}{159} & 302 & \\
\hline \multicolumn{2}{|c|}{ Repair and Maintenance Operational Unit } & \multicolumn{2}{|c|}{530} & 3,043 & \\
\hline \multicolumn{2}{|l|}{ Personnel Affairs Central } & \multicolumn{2}{|c|}{4,800} & 3,000 & \\
\hline Unit I & & \multicolumn{2}{|c|}{100} & 75 & 467 \\
\hline \multirow{2}{*}{\multicolumn{2}{|c|}{$\begin{array}{l}\text { Unit II } \\
\text { Beytepe Health Center }\end{array}$}} & \multicolumn{2}{|c|}{200} & 70 & \\
\hline & & \multicolumn{2}{|c|}{190} & 200 & \\
\hline Unit of Environmental Planning & & \multicolumn{2}{|c|}{212} & 230 & \\
\hline Unit of Beytepe Dormitory & & \multicolumn{2}{|c|}{511} & 340 & \\
\hline Student Scholarship Office & & \multicolumn{2}{|c|}{0} & 0 & \\
\hline Office for Civil Defense & & \multicolumn{2}{|c|}{159} & 82 & \\
\hline Security and Defense Office & & \multicolumn{2}{|c|}{550} & 750 & \\
\hline Office for Cafeterias & & \multicolumn{2}{|c|}{638} & 268 & \\
\hline Total & & 10,1 & & 6,085 & \\
\hline \multirow[t]{2}{*}{ Total for campus as a whole } & & \multicolumn{2}{|c|}{127,983} & 125,091 & Table VI. \\
\hline & Outgoing & Percentage & Incoming & Percentage & \\
\hline Departments & 41,129 & 32 & 53,607 & 42 & \\
\hline Deans' Offices & 40,767 & 32 & 30,978 & 25 & \\
\hline Institutes, Schools, and Research Centers & 17,525 & 14 & 14,810 & 12 & Table VII. \\
\hline Presidency and other Administrative Units & 18,188 & 14 & 17,028 & 14 & Total incoming and \\
\hline External Correspondence & 10,374 & 8 & 8,668 & 7 & outgoing records of \\
\hline Total & 127,983 & 100 & 125,091 & 100 & main units \\
\hline
\end{tabular}

Results of the administrative analysis: HU records management practices

This section of the study includes the results from the part of the questionnaire about records practices and problems. This survey was conducted with staff who executed record procedures in $\mathrm{HU}$ units. As mentioned before in the methodology section, the questionnaire respondents were analyzed as groups, selected according to the HU administrative hierarchy. The aim of administrative analysis is to identify the present situation of the administrative management systems, investigate the problems of the record system, and then to use the results to reorganize the records management system. Because the participants were able to select more than one choice, the total rates in the tables below are sometimes more than 100 percent. Table VIII identifies problems in the $\mathrm{HU}$ records system as prioritized by respondents.

According to Table VIII, staff who executed or were responsible for records procedures at $\mathrm{HU}$ identified lack of a records management program as one of the most important problems for campus record processes (65.6 percent). Lack of retention schedules was ranked as the second most important problem (60.2 percent). Third were duplication of records in various units and lack of a central university archive (59.1 percent each), and fourth was inefficiency of administrative and legal regulations (44.1 percent). Table IX lists the retention periods of records within groups of HU units as defined in Table I.

Data in Table IX indicate that all three groups kept records permanently in the repositories as a general practice without any disposition action (general ratio 


\section{$\mathrm{AP}$ \\ 61,5}

468

Table VIII.

Problems in the HU

records system

\begin{tabular}{lcccc}
\hline & $\begin{array}{c}\text { Identified as a } \\
\text { problem }\end{array}$ & Percentage & $\begin{array}{c}\text { Not identified as } \\
\text { a problem }\end{array}$ & Percentage \\
\hline $\begin{array}{l}\text { Duplication of records in } \\
\text { various units }\end{array}$ & 110 & 59.1 & 76 & \\
$\begin{array}{l}\text { Poor procedures and policies } \\
\text { Lack of retention schedules }\end{array}$ & 82 & 44.1 & 104 & 40.9 \\
$\begin{array}{l}\text { Lack of central university } \\
\text { archive }\end{array}$ & 112 & 60.2 & 74 & 39.9 \\
$\begin{array}{l}\text { Lack of records management } \\
\text { program }\end{array}$ & 110 & 59.1 & 76 & 40.9 \\
& 122 & 65.6 & 64 & 34.4 \\
\hline
\end{tabular}

\begin{tabular}{|c|c|c|c|c|}
\hline & Group I & Group II & Group III & Total \\
\hline \multicolumn{5}{|l|}{1 Year } \\
\hline$n$ & 0 & 1 & 0 & 1 \\
\hline $\begin{array}{l}\text { Percentage } \\
2 \text { Year }\end{array}$ & 0 & 2.3 & 0 & 0.7 \\
\hline$n$ & 2 & 0 & 0 & 2 \\
\hline $\begin{array}{l}\text { Percentage } \\
5 \text { Year }\end{array}$ & 4.3 & 0 & 0 & 1.4 \\
\hline$n$ & 14 & 8 & 14 & 36 \\
\hline $\begin{array}{l}\text { Percentage } \\
10 \text { Year }\end{array}$ & & 24.7 \\
\hline$n$ & 10 & 8 & 2 & 20 \\
\hline $\begin{array}{l}\text { Percentage } \\
20 \text { Year }\end{array}$ & 21.7 & 18.6 & 3.5 & 13.7 \\
\hline$n$ & 0 & 1 & 0 & 1 \\
\hline Percentage & 0 & 2.3 & 0 & 0.7 \\
\hline \multicolumn{5}{|l|}{ Permanently } \\
\hline$n$ & 18 & 25 & 37 & 80 \\
\hline $\begin{array}{l}\text { Percentage } \\
\text { Other }\end{array}$ & 39.1 & 58.1 & 64.9 & 54.8 \\
\hline$n$ & 2 & & 4 & 6 \\
\hline Percentage & 4.3 & & 7.0 & 4.1 \\
\hline \multicolumn{5}{|l|}{ Total } \\
\hline$n$ & 46 & 43 & 57 & 146 \\
\hline Percentage & 100 & 100 & 100 & 100 \\
\hline
\end{tabular}

54.8 percent; 64.9 percent of records for Group III, 58.1 percent for Group II, but 39.1 percent for Group I). On the other hand, legal regulations defining record keeping practices specify that the maximum records retention period will be five years for units and 15 years for the central archives (TC Gazette, 1988). Table X identifies the records retention procedures within groups of units at $\mathrm{HU}$.

Analysis shows that dated records at $\mathrm{HU}$ are generally transferred collectively to repositories without any disposition action (general ratio 54 percent). This is a common practice for all three groups. A total of 18.8 percent of Group I, 44.7 percent of Group II and 45.0 percent of Group III indicated that they appraise their records according to administrative and legal value after the active period. No response was received from Group III concerning "Dated records are destroyed collectively," but 6.3 percent of 


\begin{tabular}{|c|c|c|c|c|c|}
\hline & Group I & Group II & Group III & Total & $\begin{array}{l}\text { Quality records } \\
\text { management }\end{array}$ \\
\hline \multicolumn{6}{|c|}{ Dated records are destroyed collectively } \\
\hline$n$ & 3 & 4 & NA & 7 & \\
\hline Percentage & 6.3 & 8.5 & & 4.5 & \\
\hline \multicolumn{6}{|c|}{ Records are separated by priority and classified in archives } \\
\hline$n$ & 9 & 21 & 27 & 57 & 469 \\
\hline Percentage & 18.8 & 44.7 & 45.0 & 36.8 & \\
\hline \multicolumn{6}{|c|}{ Dated records are transferred collectively to repository without arrangement } \\
\hline$n$ & 35 & 19 & 30 & 84 & \\
\hline Percentage & 72.9 & 40.4 & 50.0 & 54.2 & \\
\hline \multicolumn{6}{|c|}{ Dated records are sent to university archive } \\
\hline$n$ & 1 & 3 & 3 & 7 & \\
\hline Percentage & 2.1 & 6.4 & 5.0 & 4.5 & Table X. \\
\hline Total & & & & & Records retention \\
\hline$n$ & 48 & 47 & 60 & 155 & procedures within groups \\
\hline Percentage & 100 & 100 & 100 & 100 & of units at $\mathrm{HU}$ \\
\hline
\end{tabular}

Group I and 8.5 percent of Group II reported this procedure. "Dated records are sent to university archive" was reported by 4.5 percent of participants even though HU has no central university archives. Table XI analyzes respondents' indication of the need for a comprehensive records management program at $\mathrm{HU}$, as indicated on a five-point Likert scale: $1=\mathrm{SD}$, Strongly disagree; $2=\mathrm{D}$, Disagree; $3=\mathrm{N}$, Neutral; $4=\mathrm{A}$, Agree; $5=\mathrm{SA}$, Strongly agree.

According to Table XI, HU participants who executed records procedures greatly anticipated the implementation of a comprehensive records management program. Nearly, 90 percent of Group I, 82 percent of Group II, and 72 percent of Group III indicated this need. Responses in general accumulated in the Strongly Agree (SA) section. Participants who reported no need for a new archive or records program were less than 12 percent of all three groups (total of Strongly disagree (SD) and Disagree (D) options). In contrast, more than 70 percent of Group III participants marked Agree (A) or Strongly agree (SA). Table XII lists potential benefits of a records retention program as part of a records management program at $\mathrm{HU}$.

\begin{tabular}{|c|c|c|c|c|c|c|c|c|c|}
\hline & Strongly disagree & Disagree & Neutral & Agree & Strongly agree & Total & $\bar{X}$ & $s$ & \\
\hline \multicolumn{10}{|l|}{ Group I } \\
\hline$n$ & & 1 & 10 & 35 & 7 & 53 & 3.9057 & 0.6283 & \\
\hline $\begin{array}{l}\text { Percentage } \\
\text { Group II }\end{array}$ & & 1.9 & 18.9 & 66.0 & 13.2 & 100 & & & \\
\hline$n$ & 3 & 2 & 3 & 30 & 7 & 45 & 3.8000 & 0.9909 & \\
\hline $\begin{array}{l}\text { Percentage } \\
\text { Group III }\end{array}$ & 6.7 & 4.4 & 6.7 & 66.7 & 15.6 & 100 & & & \\
\hline$n$ & 4 & 3 & 10 & 30 & 16 & 63 & 3.8095 & 1.0755 & \multirow{4}{*}{$\begin{array}{l}\text { Table XI. } \\
\text { Need for a records } \\
\text { management } \\
\text { program HU }\end{array}$} \\
\hline $\begin{array}{l}\text { Percentage } \\
\text { Total }\end{array}$ & 6.3 & 4.8 & 15.9 & 47.6 & 25.4 & 100 & & & \\
\hline$n$ & 7 & 6 & 23 & 95 & 30 & 161 & 3.8385 & 0.9213 & \\
\hline Percentage & 4.3 & 3.7 & 14.3 & 59.0 & 18.6 & 100 & & & \\
\hline
\end{tabular}


AP

61,5

470

Table XII.

Potential benefits of a records retention program
Participants reported that one of the most important reasons for implementing a records retention program would be the positive effect of a standardization of the records procedures (62.4 percent). Other benefits in decreasing order of importance were efficiency of records operations (59.1 percent), avoiding the storage of unnecessary records (59.1 percent), and increasing quality while decreasing costs (38.2 percent). Only 11.3 percent of participants indicated that no benefit would be provided by the implementation of a records retention program.

Table XIII analyzes participants' attitudes concerning the possible effects of a records management and retention program in terms of a quality-based administrative structure, as indicated on a five-point Likert scale: $1=\mathrm{SD}$, Strongly disagree; $2=\mathrm{D}$, Disagree; $3=\mathrm{N}$, Neutral; $4=\mathrm{A}$, Agree; $5=\mathrm{SA}$, Strongly agree.

The analysis shows that records procedures in each three group would be affected positively if the university decided to implement a records management and retention program in terms of a quality-based administrative structure (Total 74 percent): 78.8 percent of Group I, 70.9 percent of Group II, and 73 percent of Group III supported such a reconstruction within the institution marking Agree and Strongly agree.

\section{Overview of the analysis}

The most important problem of the HU administrative system as reported by staff who executed or were responsible for records procedures was a bureaucracy slow to communicate and unable to deal with its workload. Staff working conditions and inefficient records procedures were reported as the next most important problems. These three problems were indicated by more than 50 percent of participants.

\begin{tabular}{lrcrcr}
\hline & \multicolumn{2}{c}{ Indicated as benefit } & \multicolumn{2}{c}{ Not indicated as benefit } \\
& $n$ & $\%$ & $n$ & Total \\
\hline Standardization of procedures & 116 & 62.4 & 70 & 37.6 & 186 \\
Efficiency of records operations & 110 & 59.1 & 76 & 40.9 & 186 \\
Increase quality, decrease cost & 71 & 38.2 & 115 & 61.8 & 186 \\
Avoid needless records storage & 110 & 59.1 & 76 & 40.9 & 186 \\
No benefit & 21 & 11.3 & 165 & 88.7 & 186 \\
\hline
\end{tabular}

Table XIII.

Positive effects of a records management and retention program in terms of a quality-based administrative structure at $\mathrm{HU}$

\begin{tabular}{lcccccccc}
\hline & Strongly disagree & Disagree & Neutral & Agree & Strongly agree & Total & $\bar{X}$ & s \\
\hline Group I & & & & & & & & \\
$n$ & 0 & 4 & 6 & 35 & 2 & 47 & 3.7447 & 0.6746 \\
$\begin{array}{l}\text { Percentage } \\
\text { Group II }\end{array}$ & & 8.5 & 12.8 & 74.5 & 4.3 & 100.0 & & \\
$n$ & 1 & 2 & 10 & 24 & 7 & 44 & 3.7727 & 0.8590 \\
Percentage & 2.3 & 4.5 & 22.7 & 54.5 & 15.9 & 100.0 & & \\
Group III & 1 & 4 & 12 & 30 & 16 & 63 & 3.8889 & 0.9178 \\
$n$ & 1.6 & 6.3 & 19.0 & 47.6 & 25.4 & 100.0 & & \\
$\begin{array}{l}\text { Percentage } \\
\text { Total }\end{array}$ & 2 & 10 & 28 & 89 & 25 & 154 & 3.8117 & 0.8305 \\
$n$ & & 6.5 & 18.2 & 57.8 & 16.2 & 100.0 & & \\
Percentage & 1.3 & & & & & & &
\end{tabular}


One of the other problems reported was the lack of a records management program; more than 65 percent of participants indicated the need for implementing a comprehensive records management program. Like all institutions, HU has a records system for the creation, use, and disposition of records; however, to describe this system as a records management program would be inaccurate, because of the lack of comprehensive approaches and non-compliance with international standards such as ISO 15489, MoReq, etc. As a consequence, records system problems negatively affect not only records procedures but also the administrative structure.

Survey responses indicate that all campus groups have similar records keeping practices, as a general practice keeping records permanently. One important reason for this may be the fear of destroying needed records by mistake because of the lack of a records retention program. As mentioned before, Turkish legal regulations define records keeping practices (TC Gazette, 1988). After the active period, records are to be sent to permanent repositories, for example, to the national archives. Because of the lack of comprehensive retention schedules, records take up a great deal of space and are difficult to retrieve.

Analysis shows that as a general practice, administrative and academic units of $\mathrm{HU}$ sent dated records collectively to repositories without evaluation (54 percent). Only 36 percent of units reported appraising and disposing of records. In addition, 6.3 percent of Group I and 8.5 percent Group II (Table X) reported destroying records without any evaluation activity - a procedure which could result in dangerous problems. Such problems could be avoided with a records management program. In support of this, nearly 80 percent of the participants who executed or were responsible for records processes at $\mathrm{HU}$ reported the need for a comprehensive records management program.

Attaining quality is often described as success in today's organizations. To achieve quality, institutions need to consider all elements that affect institutional processes. Institutional manuals, documentation of procedures, and description of record systems are extremely important for establishing a quality system by means of system documentation. Quality-based systems require documentation activity to describe future action in light of standards, specifications, and procedures. As quality systems, all management systems need records of past practices for auditing and decision-making. The development of records management programs and the implementation of quality systems have many similarities on this point. Just as the work of developing records management programs requires documentation activities concerning the administrative and legal conditions of institutions, so do the documentation activities for developing quality systems. Thus, quality documentation and documentation for developing records management programs should be carried out together. In the end, more than 70 percent of the participants confirmed such a belief with ratings of "Agree" and "Strongly agree" (Table XIII).

\section{Conclusion and recommendations}

The research supported the hypothesis that the institutional processes associated with records could not be realized through legal and administrative necessities in Turkish public universities (example Hacettepe University) because of erroneous applications, insufficiency of legal regulations, lack of quality-based administrative structure, ineffective records management system, unqualified staff. 
AP

61,5

472

The following recommendations are made concerning Turkish public universities' records management and records retention programs in terms of quality systems:

- The educational backgrounds of staff who execute records procedures should be improved by means of orientation and other training activities.

- Attention should be paid to records problems accumulating in subunits (rather than main units) at $\mathrm{HU}$, especially as these may relate to insufficient professional education or inadequate manuals and guidelines.

- A manual explaining all record procedures and related issues should be prepared, in order to standardize procedures and prevent incompatible practices between units.

- The development of records retention programs should be a priority because of incompatible applications, the destruction of important documents, and the unnecessary bulk of records in many administrative and academic units. These kinds of programs should be developed in light of international and national standards, best practices, and studies such as this.

As staff who execute or are responsible for records issues at HU have confirmed, if all recommendations listed above were put into practice, coordination and standardization problems would be avoided, records processes would be more effective, the problem of the retention and storage of unnecessary documents would be solved, institutional decisions could be more accurate and timely, and operational practices could be realized according to legal and administrative requirements, as quality systems require.

\section{References}

Academic Ranking of World Universities (2006), Academic Ranking of World Universities: Top 500 World Universities, Shanghai Jiao Tong University, Shanghai, available at: http:// ed.sjtu.edu.cn/rank/2005/ARWU2005TOP500list.htm (accessed October 2006).

Berry, G. (1998), “A quality systems model for the management of quality in NSW schools”, Managing Service Quality, Vol. 8 No. 2, pp. 97-111.

Blow, C. (1995), "An introduction to total quality management”, Assessment Journal, Vol. 2 No. 1 , pp. 25-7.

Brumm, E.K. (1996), "The marriage of quality standards and records management", Records Management Quarterly, Vol. 30 No. 2, pp. 3-11.

Brumm, E.K. (1997), Beyond Compliance: Managing Records for Increased Protection: The ISO 9000 Handbook, Irwin, Chicago, IL.

Hacettepe Üniversitesi (2006), Akademik Personel Sayılarmın Sayısal Dağılımı, available at: www.hacettepe.edu.tr/turkce/universitemiz/faaliyet03/12.shtml (accessed February 2006).

Hacettepe Üniversitesi Strateji Geliştirme Daire Başkanlığı (2006), Bütçe uygulamalan sonuçlan konusunda kamuoyunu bilgilendirme duyurusu, available at: www.hacettepe.edu.tr/ duyuru/rekduy/butceuygulamason.pdf (accessed August 2006).

Hare, C.E. and McLeod, J. (1997), Developing a Records Management Programme, ASLIB, London.

Külcü, Ö. (2005), "Records management through quality management and quality system documentation in public universities", unpublished doctoral dissertation, Hacettepe University, Ankara. 
Langemo, M. (1995), "Successful strategies for establishing or strengthening a records management program", Your Highway to Information Management: Proceedings of the ARMA International 40th Annual Conference, Nashville, October 22-25, 1995, ARMA International, Prairie Village, KS, p. 515.

Montaña, J. (1997), "Statutes of limitation and records retention", Records Management Quarterly, Vol. 31 No. 1, pp. 46-63.

Penn, I.A., Pennix, G. and Coulson, J. (1994), Records Management Handbook, 2nd ed., Gower, Aldershot.

Rao, A., Carr, L.P. and Dambolena, I. (1996), Total Quality Management: A Cross Functional Perspective, Wiley, New York, NY.

Schlickman, J. (2003), ISO 9001:2000: Quality Management System Design, Artech House, Boston, MA.

Skupsky, D.S. (1994), Records Retention Procedures, Information Requirements Clearinghouse, Englewood, CO.

TC Gazette (1988), No. 19949, October 4.

\section{Corresponding author}

Özgür Külcü can be contacted at: kulcu@hacettepe.edu.tr
Quality records management

473

To purchase reprints of this article please e-mail: reprints@emeraldinsight.com Or visit our web site for further details: www.emeraldinsight.com/reprints 